\title{
Improving supply chain flexibility and agility through variety management
}

\author{
Juneho Um
}

\begin{abstract}
Purpose - A trade-off exists between product variety and supply chain (SC) performance. To help mitigate the impact on SC of increased product variety, this paper examines how variety-management activities including variety management strategy, supplier partnerships and close customer relationships affect SC flexibility and agility at different levels of customisation.

Design/methodology/approach - A survey-research methodology is employed using data from 363 manufacturing firms from the UK and South Korea. In particular, cluster analysis and structural equation modelling were used to evaluate the proposed model according to the level of customisation.

Findings - The results suggest that internal variety-management strategy and external SC integration have a positive influence on SC flexibility and agility. Customer relationships and variety-management strategies influence SC flexibility more than partnerships with suppliers whereas variety-management strategies and partnerships with suppliers influence SC agility more than customer relationships. In fact, for external integration in particular, customer relationships influence SC flexibility (i.e., reaction capability) rather than agility (i.e., reaction time) whereas partnerships with suppliers influence SC agility rather than flexibility. In a high-customisation context, close customer relationships are the most effective way to increase SC flexibility, whereas partnerships with suppliers are the most effective way to increase SC agility. In a low-customisation context, a variety management strategy and customer relationships are the most effective way to increase both SC flexibility and agility.

Originality/Value - This paper suggests key variety management activities to aid managers to better manage product-variety ambitions in SC under varying customisation profiles through internal and external approaches.
\end{abstract}

Keywords: Product variety management, Supply chain flexibility, Supply chain agility, Customisation Paper type: Research Paper 


\section{Introduction}

Today's supply chain (SC) managers recognise that their roles are becoming more complex, mainly as a result of rapid changes, globalisation and especially uncertain business environments. Lack of understanding of the complexity of drivers and poorly designed and executed strategies to address this complexity make SC decisions much more difficult, often leading to undesirable outcomes (Manuj and Sahin, 2009). In an ideal world, SC should be designed from the 'customer backwards' rather than by the conventional approach that has a tendency to be from the 'factory outwards'. The temptation is to create SC that is more focused on the goal of 'efficiency' rather than that of 'effectiveness' (Christopher et al., 2006). For products with highly customised options, product variety can be an especially challenging driver of complexity, which can disrupt the SC (see van Donk and van Dam 1996; Faber et al., 2002). Most manufacturers recognise that a trade-off exists between product variety and SC performance (Thonemann and Bradley, 2002). High product variety leads to an increase in sales and market share, but it can also add complexity to demand forecasting and create difficulties in aligning supply with demand in the SC (Whang and Lee, 1998; Randall and Ulrich, 2001). Although the initial impact of product variety on sales is positive, beyond a certain level, increased product variety may gradually lead to lower sales (Wan et al., 2012). Therefore, companies that need to increase product variety should consider the potentially negative impacts on SC performance such as complexity in design, manufacturing and scheduling as well as cost of production and market mediation.

To optimise the trade-off between product variety and SC performance, manufacturers manage product variety by limiting it through focused manufacturing or increased flexibility (Kekre and Srinivasan, 1990; Yeh and Chu, 1991; Gerwin, 1993; De Groote, 1994; Silveira, 1998). However, when considering long term profits and competition for market share as demand uncertainty increases, continuous improvement in flexibility and agility offers a more 
competitive method of responding to customer needs. Organisations may focus on either SC flexibility or SC agility to achieve the appropriate response capability, and this is often better than considering both aspects. Also, organisations' SC agility can be impacted by the synergy between the flexibilities in the SC process (Swafford et al., 2006). To manage increased product variety and customisation, SC should be immediately responsive to a constantly changing market (Yang and Burns, 2003). Flexibility and agility have repeatedly been shown to enhance an organisation's ability to effectively react to disruptions in the SC (Skipper and Hanna, 2009). Supply chain flexibility and agility also have a positive influence on both resource efficiency and customer service (Narasimhan and Jayaram, 1998; Hiroshi and David, 1999; Tummala et al., 2006). Supply chain performance includes these cost-efficiency and customer-service indicators (Tummala et al., 2006) whereas, in this research, SC flexibility and agility are defined in terms of SC responsiveness in managing product variety.

Given that maintaining SC flexibility and agility remains crucial for managing varietyrelated issues, what are the most effective variety management activities to optimise the tradeoff between product variety and SC performance? What are the most effective variety management activities to improve SC flexibility and agility, respectively? First, adopting internal variety management strategies (VMSs) such as modularity (i.e., a product-based strategy), cellular manufacturing (i.e., a process-based strategy) and postponement (i.e., a structure-based strategy) has proven essential to achieving SC flexibility and agility (Qiang et al., 2001; Nair 2005; Scavarda et al., 2010; Jacobs et al., 2011; Patel and Jayaram, 2014). However, are internal variety strategies sufficient to mitigate the trade-off between product variety and SC performance? Firms can often best appropriate the benefits of innovation by opening their technology to an outside network of cooperating partners because the development of a modular concept and systems can lead to vertical and horizontal disintegration (Langlois and Robertson, 1992). Therefore, a second, external integration of 
supplier and customer is another crucial driver in managing variety issues and promoting the modular concept. External integration emphasises collaboration with the upstream and downstream partners. To respond to customer needs, an increasing number of organisations are attempting to develop partnerships with suppliers and customers (Slack and Chambers, 2007), suggesting that SC integration that focuses on both demand and supply is required to handle the increased complexity and uncertainty caused by product variety (Fisher, 1997; Mendelson and Pillai, 1999; Heikkilä, 2002). According to Vickery et al. (2003), two fundamental practices that accomplish integration across a SC are supplier partnering and the establishment of closer customer relationships. Partnership with suppliers to ensure high product quality and low cost entails earlier supplier involvement in product design, or acquiring access to suppliers with superior technological capabilities (Narasimhan and Das, 1999). Close customer relationships enable firms to seek information about customer preferences and needs, which enables firms to become more responsive. Insights gained by establishing strong relationships with customers can also be used to enhance operational effectiveness and cost efficiency (Vickery et al., 2003). Integration of the SC through supplier partnerships and close customer relationships can be crucial, especially for management of product variety and new product development (NPD). Also, external integration has been demonstrated to be positive to cost, delivery, quality and flexibility (Mackelprang et al., 2014).

However, variety-related issues require considering customer involvement (i.e., customisation). Products can be differentiated according to the stage in the value chain where customisation occurs; this is the point at which customer input is injected (Lampel and Mintzberg, 1996). For example, the success of Dell as a mass customiser is due to the late differentiation point and postponement strategy employing make-to-order operation. Postponing customisation by employing various decoupling points allows a SC to react more readily to changes in customer demands (Mason-Jones and Towill, 1999). However, the 
strategic focus such as lean or agile in SC functions differs according to the degree of customisation (Agarwal et al., 2006; Stavrulaki and Davis, 2010). Also product customisation determines the amount of flexibility required of a SC (Sengupta et al., 2006). Therefore, the level of customisation can be determined by companies' strategies to support the required variety management, which can affect the level of SC flexibility and/or agility to different degrees.

To identify a process to optimise the trade-off between product variety and SC performance, the present study examines how internal variety management strategies and external SC integration separately influence SC flexibility and agility and explores the implications for SC management with different levels of customisation. Compared with previous empirical researches (e.g., Ramdas and Randall, 2008; Thonemann and Bradley, 2002; Fisher et al., 1999; Fisher et al., 1995), this study makes several critical contributions to practices. First, two distinct performance approaches are required to manage variety issues: SC flexibility and agility, which are frequently employed interchangeably without clear definitions in academics and in practice. Second, the overall variety management activities are designed by considering both internal and external aspects: internal VMS in operations (i.e., modularity, cellular manufacturing and postponement) and external integration (i.e., partnerships with suppliers and close customer relationships). These two approaches provide extensive guidelines for increasing product variety. Finally, the study assesses how the moderating factor embodied by different degrees of customisation affects the relationships between variety management activities and SC flexibility or agility. This approach provides suggestions for a company's strategic focus based on its level of customisation. In addition, this study suggests insights for SC managers by providing the empirical evidence they require to support their companies' decision-making developments regarding product variety. 
A number of studies have investigated theoretical approaches to managing the complexity in the SC that results from product variety (Blecker and Abdelkafi, 2006; Ramdas and Ulrich, 1999; Yeh and Chu, 1991), whereas others have empirically investigated the impact of product variety on particular dimensions such as time and cost (Thonemann and Bradley, 2002) or have focused on restricted sectors such as the automotive industry (Fisher, Ramdas and Ulrich, 1999; Fisher et al., 1995) or on a specific strategy such as modularity (Ramdas and Randall 2008; Yadav et al. 2011). However, no attempt appears in the literature to demonstrate discrete procedures for handling variety issues through the consideration of diverse approaches, such as internal and external drivers with distinct levels of SC flexibility and agility in various manufacturing industries. This approach can provide a theoretical foundation to explain how to handle variety-related issues and their impact on the SC. In addition, the impact of potential moderating factors such as customisation on managing the increase in variety has not been determined empirically. In reality, companies with differing levels of customisation require different approaches and strategies for the SC because of their differing product characteristics and levels of product variety (see Lampel and Mintzberg, 1996; Agarwal et al., 2006; Stavrulaki and Davis, 2010).

\section{Conceptual model and development of hypotheses}

\subsection{Supply chain flexibility and agility}

Although flexibility and agility can be both dimensions of SC performance (Beamon 1999; Swafford et al., 2006), it is important to distinguish between them. A firm attains SC agility by tapping various synergies in different forms of SC flexibility (Agarwal et al., 2006). In this

paper, SC flexibility is concerned with the internally focused capability and adaptability of a firm's internal SC functions including purchasing, engineering, manufacturing and distribution at the operations level, while SC agility represents an externally focused competency concerned 
with speed at the business level, such as rapid market responsiveness, lead time reduction, delivery reliability and frequency of product introduction (Christopher and Towill, 2001; Swafford et al., 2008). While these measures may resemble performance metrics, they are conceptually different in that SC agility represents how rapidly outcomes can be changed (i.e., responsiveness capability), and not the level of functional attainment of these outcomes (i.e., performance or reaction capability). Swafford et al. (2006) employed SC agility item measures that capture the concept of the speed with which a firm's SC can respond. For example, SC agility measures imply how quickly a firm can reduce manufacturing lead times or increase customer service levels but does not imply the level of lead time performance or customer service performance (see Swafford et al. 2006).

Bernardes and Hanna (2009) also clarified conceptual disparities between the terms flexibility, agility and responsiveness, which are used inconsistently and ambiguously in operations management. Supply chain flexibility is a separate and antecedent capability required for SC agility (Agarwal et al., 2006; Bernardes and Hanna, 2009). Both SC flexibility and agility have a positive influence on SC performance indicators, such as cost efficiency and customer service (Hiroshi and David, 1999; Tummala et al., 2006). In addition, SC flexibility and agility are essential capabilities required to mitigate the trade-off between product variety and SC performance (Scavarda et al., 2010). Some researchers included SC flexibility as a dimension of SC performance (e.g., Beamon, 1999; Khan et al., 2009). However, in the present research, SC flexibility and agility were used as performance indicators for SC reaction and responsiveness in managing variety issues.

Items identified as dependent variables including SC flexibility and agility are taken from the conceptual framework of Swafford et al. $(2006,2008)$, which divides SC flexibility attributes into three processes: procurement or sourcing, manufacturing and distribution or logistics. Based on this framework, Swafford et al. (2006) identified six items for SC flexibility and 
seven for SC agility. Thus, SC flexibility can involve: (1) production volume, production mix and engineering change flexibility in manufacturing (i.e., items 3, 4 and 5); (2) flexibility in procurement to change material orders (quantity and time; i.e., items 1 and 2); and (3) delivery flexibility in distribution (i.e., item 6). However, SC agility relates mainly to the speed of manufacturing and distribution activities in the SC. Improving SC agility requires: (1) reducing the product development cycle time and the manufacturing and delivery lead time (i.e., items 1, 2 and 7); (2) increasing the level of product customisation in manufacturing (i.e., item 3); and (3) improving customer service (i.e., item 4), delivery reliability (i.e., item 5) and responsiveness to market needs (i.e., item 6).

\subsection{Internal variety management strategy}

The study defines three activities as fundamental in explaining the structure of internal variety management strategies to mitigate the negative impact of product variety on the SC. Scavarda et al. (2010) also suggested three types of operational strategy that can optimise the trade-off between product variety and SC performance. First, changes in product architecture (i.e., use of product modularity) reduce complexity and costs associated with product development, sourcing and manufacturing. Second, flexible manufacturing operations such as cellular manufacturing lead to cost-efficient production. Finally, postponement of product configuration decisions reduces the impact of demand uncertainty resulting from product variety (Scanvarda et al., 2010; Patel and Jayaram, 2013). For example, positioning the inventories in centralised distribution operations decreases the cost of market mediation. Similarly, Blecker and Abdelkafi (2006) divided VMSs into product levels such as product modularity, process levels such as component families (i.e., process modularity) and delayed differentiation. All three strategies are supported by modular product design and promoted by the paradigm of a 'decoupling point', which decides the level of customisation. Patel and 
Jayaram (2013) supported the concept that product modularity and process modularity improve operational performance, including labour, material handling, mix and modification flexibility. Thus, the present research considers three representative strategies: modularity, cellular manufacturing (i.e., component family) and postponement as product, process and structural approaches, respectively. First, the latent variable VMS refers herein to an internal activity to mitigate the trade-off between product variety and SC performance by enhancing SC flexibility and agility. Next, VMS is identified and represented by three available management strategies (i.e., modularity, cellular manufacturing and postponement strategy) as observed variables based on the measures derived from a literature review (see Table 1).

In an early study, Fisher et al. (1999) suggested process- and product-based strategies to accommodate increased product variety. First, process-based strategies provide production and distribution with sufficient flexibility to handle high variety at a reasonable cost. For example, when using group technology principles in cellular manufacturing, parts with similar design characteristics and processing requirements are grouped into families that lead to operational flexibility (Abdi and Labib, 2004). Second, product-based strategies such as modularity enable product designs that allow high variety while maintaining low component variety in production and distribution (Fisher et al., 1999). Cost increase in SC due to variety increase can be arrested to some extent by modularisation (Syam and Bahatnagar, 2015). Shared components increase economies of scale, simplify production and scheduling processes and lower inventory costs (Patel and Jayaram, 2013). The implications of product modularity stretch beyond the boundaries of a firm's value chain because they allow the firm to reconfigure supply, manufacturing and distribution networks (Salvador et al., 2004). Lastly, an obvious relationship exists between configuration of a SC and postponement (Van Hoek, 1999): as a structure-based strategy, postponement can reduce the impact of demand uncertainty and support more product variety (e.g., Dell's mass customisation). This approach has recently 
received considerable attention as a way to reduce the costs and risks of product variety while improving SC flexibility (Davila and Wouters, 2007; Scanvarda et al., 2010; Patel and Jayaram, 2013). Therefore, the research proposes the following hypothesis:

H1a. An internal VMS correlates positively with SC flexibility.

Supply chain agility can be achieved by cellular production based on the Pareto Law (see Christopher and Towill, 2001) Cellular production is supported by modular-designed products or parts, resulting in greater agility. Agrawal and Hurriyet (2004) also pointed out that cellular production, whereby similar parts are grouped into families based on shapes or production processes, reduces the complexity created by large-scale production and facilitates the production of a variety of products. In particular, cellular manufacturing reduces lead time and thus accelerates agile production and distribution in the SC. Regarding product-based strategies, Jacobs et al. (2011) argued that product modularity facilitates process modularity, engenders agility and improves market growth. Product modularity also supports delayed differentiation (Salvador et al., 2004). Postponement as a structure-based strategy enables manufacturers to improve inventory turnaround, asset productivity and SC flexibility and facilitates fast delivery, resulting in improved customer service (Nair, 2005; Davila and Wouters, 2007). To achieve the agile paradigms in the SC, Christopher and Towill (2001) suggested the 'decoupling-point' approach, which can be supported by modular production and postponement strategies. Therefore:

H1b. An internal VMS correlates positively with SC agility.

\subsection{External supply chain integration}

Partnership with suppliers 
External integration boosts SC flexibility. Benefits of external collaboration through integration often emerge when partners are willing to work together by sharing information and resources to achieve collective goals (Stank et al., 2001). Various competencies are required to integrate a firm's internal capabilities with those of its external partner (Whipple et al., 2015). Sharing sensitive financial, design and research information strengthens trust in a partnership and enables a quick response to customer needs. Thus, by integrating a crossfunctional team with suppliers, manufacturers enhance not only communication flows but also product development (Ngai et al., 2004; Tummala et al., 2006). Joint problem solving and performance evaluations with suppliers are critical during product development (Tummala et al., 2006). A full partnership requires sharing risks and benefits, and a SC's long-term focus should not revolve solely around price. Trust between manufacturers and suppliers should encourage extensive knowledge sharing and build deeper relationships (Liao et al., 2011), which in turn can reduce uncertainty. Sharing sensitive information such as cost (Ngai et al., 2004) and creating close partnerships, especially during product development, are crucial (Cousins et al., 2011). Das et al. (2006) also stressed the importance of supplier integration, which involves elements such as joint problem solving, mutual trust, joint investment and sharing financial information. These types of partnership with suppliers lead to SC flexibility through enhanced synchronisation of purchasing and production functions. Especially close relationships have a positive influence on volume, mix and new-product flexibility (Suarez et $a l ., 1996)$, which can result in SC flexibility by leading to enhanced mutual commitment and improved communication. Therefore, as an external integration activity:

H2a. Supplier partnerships correlate positively with SC flexibility.

Supplier partnerships relate positively with product-development success (Groves and Valsamakis, 1998; Tan and Kannan, 1998). Tan and Kannan (1998) found that supplier 
knowledge and skills play a significant role in reducing production costs. The early formation of close relationships with suppliers is critical for a company during product innovation and development (Power et al., 2001; Carr and Kaynak, 2007; Cousins et al., 2011). Supplier involvement also influences turnover (Faems et al., 2005), product innovation (Nieto and Santamaria, 2007) and other performance criteria, such as product cost, quality and time to market (Clark and Fujimoto, 1991; Ragatz et al., 1997). Supplier alliance in particular can promote greater coordination and faster response of the SC to market changes (Zsidisin and Ellram, 2001). For example, with the advent of business-to-business (B2B) electronic commerce, firms are exploring alternative long-term relationships with their suppliers to improve SC agility (Handfield and Nicholas, 2002). Therefore, partnerships with suppliers as an external integration activity can lead to SC agility, leading to the following hypothesis:

H2b. Supplier partnerships correlate positively with SC agility.

\section{Close customer relationship}

Many factors determine product variety including customer requirements, market competition and customisation (Silveira, 1998), so it is vital that each SC participant adds value by providing the best product or service from the perspective of customers in an SC (Jeong and Hong, 2007). Not only the product, but also the entire SC from procurement of raw material to the final point of consumption, should be effectively and efficiently managed to meet the endconsumer's requirement for product and service value (Zokaei and Hines, 2007). Fisher et al. (1995) argue that companies need a market strategy to minimise unwanted product variety and propose two strategies: (a) closer relationships with customers to ensure current products reflect customer needs, and (b) eliminating products that are no longer beneficial. Child et al. (1991) suggest that companies must assess the variety that customers find attractive, avoiding confusion from information overload that results in withdrawal from purchasing decisions. To 
build stronger customer relationships, gathering customer feedback from a SC is required to help identify changing customer specifications (Tummala et al., 2006). Following up on customer feedback and evaluating customer complaints are crucial to building close customer relationships (Tan et al., 1999; Ranganathan et al., 2004; Wang and Feng, 2012). Monitoring customer service and responding to customers' evolving needs are also essential to building close customer relationships (Power et al., 2001; Zokaei and Hines, 2007; Wang and Feng, 2012). Understanding customer needs through close customer relationships can lead to SC flexibility in the form of, for example, product, volume and delivery flexibility. In comparison with supplier management, customer management is highly demand-focused. An accurate understanding of customer requirements and demand is an increasingly important component in enhancing the flexibility of a SC (Tracey and Tan, 2001). Therefore, SC flexibility can be enhanced by external integration activities that lead to closer customer relationships:

H3a. Closer customer relationships correlate positively with SC flexibility.

Supply-chain agility aims for responsiveness to customers and customer service. This is exemplified by co-creation, which has become popular in recent years (Lusch et al., 2007; Michel et al., 2008). User involvement is especially useful for capturing consumers' latent needs, the knowledge of which is crucial to successful new-product development (Kristensson et al., 2008). Co-creation by customer involvement can be one of the most effective methods of managing product variety, and close customer relationship management (CRM) achieves this aim. CRM is the management of technology, processes, information and people to maximise customer contact (Galbreath and Rogers, 1999). CRM can result in high customer satisfaction, which is achieved through customisation, personal relationships and after-sales support (Galbreath and Rogers, 1999). 
Heikkilä (2002) points out the need to shift from the supply side to the demand side of SC management. Improved access to demand information throughout the SC permits rapid and efficient delivery, coordinated planning and better logistics communication (Treville et al., 2004), resulting in SC agility. Handfield and Bechtel (2002) also support the notion that a relationship of trust between buyer and supplier can improve SC responsiveness. SC agility requires firms to closely manage the legally separate but operationally interdependent parties, including suppliers, manufacturers, distributors and customers, to maintain a close and coordinating relationship (Ngai et al., 2011). Therefore, as an external integration activity, closer and coordinated relationships with customers can lead to greater SC agility in response to market needs:

H3b. Closer customer relationships correlate positively with SC agility.

Table 1 presents the independent variables, including internal VMS and external SC interrelation with supplier and customer and related literature sources.

\section{Table 1 Variety Management Activities and Related Literature}

\subsection{Customisation}

Products are distinguished according to the stage in the SC at which customisation occurs (Lampel and Mintzberg, 1996). Identifying the point of initial customer involvement, which is called the decoupling point, is critical in determining the degree of customisation (Duray et al., 2000). The customer-order decoupling point (CODP) is receiving increasing attention as an important input to the design of SCs (Olhager, 2010). Early research by Lampel and Mintzberg (1996) showed that development of a customisation framework comprises five strategies: pure standardisation, segmented standardisation, customised standardisation, tailored customisation 
and pure customisation. With pure standardisation, the customer has no direct influence on any stage of the value chain. With segmented standardisation, the customer has no direct control over design or production (i.e., distribution customisation). In customised standardisation, products are made to order at the assembly stage from standardised components. Tailored customisation occurs during fabrication to adapt to customer needs and, finally, pure customisation provides products that are specifically designed to customer specifications and are thus unique. Squire et al. (2004) associate various forms of customisation with four manufacturing functions: distribution, assembly, fabrication and design customisation. Poulin et al. (2006) provide a comprehensive view of the degrees of customisation offered, the framework of which is divided into eight categories: popularising, varietising, accessorising, parameterising, tailoring, adjusting, monitoring and collaborating.

The level of customisation is a moderating factor in this study. The customer-order decoupling point is defined as the point in the value chain of a product at which the product is linked to a specific customer order (Olhager, 2010). This point can determine the level of customisation. Therefore, different manufacturing scenarios such as make-to-stock (MTS), assemble to-order (ATO), make-to-order (MTO) and engineer-to-order (ETO) relate to different levels of customisation. Regarding the relationship between customisation and the SC, a connection between qualifiers or winners and lean or agile is essential (Christopher and Towill, 2001; Aitken et al., 2002; Agarwal et al., 2006). The lean paradigm, which typically employs low customisation, is most powerful when the winning criterion is cost (i.e., cost leadership). However, when service and customer-value enhancement (i.e., differentiation) are prime requirements of market-winning criteria, a flexible and agile paradigm that typically employs high customisation is critical (Mason and Towill 1999). Drawing from three related literature reviews (Lampel and Mintzberg, 1996; Agarwal et al., 2006; Stavrulaki and Davis, 2010), Table 2 summarises the characteristics of the types of customisation. Stavrulaki and 
Davis (2010) emphasised alignment as a key aspect of a product (e.g., functional and innovative products) and its SC processes according to four SC strategic foci (e.g., from build-to-stock to design-to-order). They highlight the importance of links between SC processes (e.g., production and logistics) and SC strategies (e.g., lean, legal and agile). For example, a flexible or agile organisation with a high level of customisation would be more effective than a lean organisation within an environment of unstable demand, because flexible or agile operations and SCs can quickly be reconfigured to reflect such demand conditions (Doran, 2005). Thus, a company's strategic focus and capabilities (i.e., a resource-based view) differ according to the level of customisation which can affect the relations between variety management activities and SC performance. Due to the nature of differences in product type, manufacturing, logistic and market focus among different levels of customisation (see Table 2), the present research uses level of customisation as a moderating factor that can have varying impacts on the relationship between product-management activities and SC flexibility and agility. For example, compared with the low-customisation context, in a high-customisation context with a large number of customer segments, customer relations can be vital to improve flexibility (i.e., reaction capability). Figure 1 shows the research model, which supports management of product variety in an SC; the level of customisation is used as a moderating factor. Therefore, the research proposes the following two hypotheses:

H4a. Variety management activities have different relationships with SC flexibility across levels of customisation.

H4b. Variety management activities have different relationships with SC agility across levels of customisation.

Table 2 General Characteristics of Customisation Types. 


\section{Figure 1. Research model.}

\section{Methodology}

\subsection{Data collection and sampling process}

Data were obtained from manufacturers in both the UK and South Korea. The aim was to investigate interdependencies between partnerships with suppliers, customer relationships, internal variety management strategy and SC flexibility and agility. The two countries apply similar technological advances in the manufacturing sector, whereas potential differences in economic development and income distribution affecting the level of product variety can be reduced by investigating companies from both countries. Following the guidelines of Craig and Douglas (1999), the original version of the questionnaire was translated into Korean by a professional translator, then translated back into English by another expert and finally scrutinised by two more translators. Manufacturing companies were randomly selected based on the standard industrial classification (SIC) code in the FAME database, and individual contacts were also made with various manufacturers in both countries. The questionnaire was put to chief executive officers, directors, managers and staff of SC, purchasing, production, logistics and sales departments. Of the 1950 questionnaires sent to manufacturing companies, 363 companies (211 UK and 152 South Korea) completed them by post, e-mail or face-to-face interviews from February to June 2012; a response rate of $19 \%$. In terms of number of employees, $59.1 \%$ of the firms were small or medium sized (SMEs) and $40.9 \%$ were large (LEs) (i.e., over 250 employees). Of all the respondents, $87 \%$ were in senior management positions. To investigate disparities with the model according to customisation, the data were divided by K-mean cluster analysis into two levels of customisation: low (mean centre = 2.15; $n=207$ ) and high (mean centre $=4.43 ; n=156$ ). Table 3 shows the types of industry in relation 
to customisation levels; equivalence between the two levels of customisation was ensured in terms of industry characteristics (Floyd and Widaman, 1995).

To assess the possibility of non-response and late-response bias, $t$-tests were conducted to compare characteristics between early and late respondents (Armstrong and Overton 1977). No differences in sales or number of employees were found, which suggests that response bias was not present. To test for common method bias, Harman's one-factor test using Podsakoff et al.'s (2003) outline was applied. A principal components factor analysis was conducted on all items, resulting in the extraction of five factors. These accounted for $68 \%$ of total variance; the first factor accounted for $19 \%$ with eigenvalues greater than 1. Since no single factor was apparent in the unrotated factor structure, common method variance was therefore unlikely.

Because samples were taken at random from the UK and South Korea, a measurement invariance test was applied by using two split samples. The test aimed to identify the critical assumption that the basic structure of the model is stable across cultures, and that individuals in different countries use its scale in a similar manner (Turker, 2009; Malham and Saucier, 2014). As can be seen from Table 4, multi-group confirmatory factor analysis (CFA) estimates were made to cross-validate the model across the two countries. The results provide acceptable fits to the data, indicating that configural invariance (i.e., the same items load on the same factor) is supported (Model 1). The factor loadings were constrained but the intercepts were allowed to vary between countries to test whether loadings were the same across countries (Model 2). Finally, both the factor loadings and intercepts were constrained to test strong measurement invariance across countries (Model 3). Comparisons between nested models were conducted by exploring chi-square difference test $\left(\Delta \chi^{2}\right)$ as well as the CFI, RMSEA and SRMR as fit indices (Chen 2007; Cheung and Rensvold 2002). The chi-square difference test between models was not significant and there was no substantial difference in fit between these models. This result proves measurement invariance, which means that the data from the two countries 
do not suggest the presence of measurement bias (Milfont and Fischer, 2010) and features of the construct indicate consistent structure within the two countries (Floyd and Widaman, 1995).

\section{Table 3 Main Products by Customisation Level}

\section{Table 4 Measurement Invariance Test across the two Countries}

\subsection{Measures}

Lampel and Mintzberg's (1996) framework was adopted for measuring the level of customisation of UK and South Korean manufacturers. More specifically, pure standardisation provides standard products that have pre-defined options and designs. Product customisation occurs at the sales stage. Second, segmented standardisation provides products in which customers specify product packaging, delivery schedules, or delivery location. The product is standard, with pre-defined options and designs. Customisation operates at sales and distribution stages. Third, customised standardisation provides various types of product, and customers are offered a number of pre-defined options. Products are assembled to customer order by using standard components, and customisation is achieved during assembly. Fourth, tailored customisation provides various types of product, and customers are offered a number of predefined designs. Products are manufactured as per a customer's order, and customisation is achieved during fabrication. Finally, pure customisation provides a unique product design, and customer input is integrated at the onset of design. Products are designed to order, and customisation is achieved during design. The reasons for employing this framework are its simplicity and wide use by researchers (see Rudberg and Wikner, 2004; Squire et al., 2004; Hendry, 2010) who have demonstrated and critiqued its elements. 
All constructs were measured by using a five-point Likert scale. Items for VMS, partnerships with suppliers and customer relationships ranged from strongly disagree (1) to strongly agree (5) by asking the company's current position in each activity. For SC flexibility and agility, respondents were asked to indicate how well your company performs in the following SC activities', and items ranged from poor (1) to excellent (5).

\subsection{Reliability and validity}

To assess reliability and validity, both exploratory factor analysis (EFA) and CFA were conducted by using AMOS 22. Five constructs (VMS, partnerships with suppliers, customer relationships, SC flexibility and agility) were assessed with CFA. After omitting two items (PS1 and FL5) due to low factor loadings $(<0.6)$, the remaining measures were re-assessed. The measurement model offered a satisfactory fit $\left(\chi^{2}[199]=535.53, \mathrm{GFI}=0.882, \mathrm{SRMR}=0.050\right.$, RMSEA $=0.068$, CFI $=0.919)$. Composite reliability $(\mathrm{CR})$ also showed acceptable internal consistency (CRs > 0.789). Convergent validity was affirmed because all factor loadings exceeded 0.6, with acceptable average variance extracted $\left(\mathrm{AVE}_{S}>0.540\right)$. No case existed such that the square of a correlation between constructs was greater than the AVE. Thus, discriminant validity was established by using the procedures outlined by Fornell and Larcker (1981).

Regarding EFA, Cronbach's alpha coefficients and factor loadings for each of the variables are reported in Table 5. All loadings exceed 0.68 except for PS1 and FL5, which were removed from analysis. Convergent validity (factor loading $>0.5$ ) existed for the five variables (Hair et al., 2010). All of Cronbach's alpha coefficients (above 0.79) showed acceptable reliability. Thus, the constructs of SC flexibility and agility were empirically proven as distinct concepts, especially through the EFA. The results of separate EFAs for both low and high customisation also showed acceptable reliability and validity with the same items loaded (i.e., 
PS1 and FL5 were removed). Thus, the variables of the construct have a consistent and stable structure across the groups (Floyd and Widaman, 1995). Regarding generalisability to the population, the result of the random-split-sample analysis (182 and 181 respondents in each) also demonstrates the commonalities of all of the items (Turker, 2009). Table 6 shows correlations and AVEs for each construct, with means and standard deviations. Therefore, results of CFA and EFA tests suggested items have high within-factor loadings, which indicates that the measures are consistent. They also show differences between factor loadings within constructs and between constructs, indicating evidence of both convergent and discriminant validity.

Table 5 Exploratory Factor Analysis

\section{Table 6 Inter-Construct Correlation Estimates and Related AVEs}

\section{Empirical results}

To compare the different relationships across the low- and high-level customisation models, multi-group structural equation modelling (SEM) was tested. In the default model, none of the path coefficients were constrained across two groups. Equality constraints were then imposed on all path coefficients, resulting in significant deterioration of the model fit $\left(\Delta \chi^{2}, p<0.01\right)$. This result indicates that at least one of the path coefficients across the groups differs significantly (Byrne, 2001; Schumacker and Lomax, 2004). Thus, models across the groups are comparable.

Three SEM analyses were conducted to discover which of the independent variables had the highest and lowest correlations with SC flexibility and agility with combined, lowcustomisation and high-customisation samples. Through the modification indices, constructs in variety management activities and two performances shared the variance respectively based 
on the model, and the empirical results of the modification indices. Combined data demonstrated an acceptable fit $(\mathrm{CFI}=0.919 ; \mathrm{NNFI}=0.906 ; \mathrm{RMSEA}=0.068 ; \mathrm{SRMR}=0.051)$, and paths had high $t$-values $(>2.151)$ with acceptable $p$-values $(<0.05)$. All latent variables showed a significant and positive impact on SC flexibility and agility. Results from the combined sample supported H1a, H1b, H2a, H2b, H3a and H3b. Table 7 shows SEM results, including path coefficients, level of significance and fit indices.

The high-customisation sample was analysed next; the results suggest VMS and customer relationships correlate with SC flexibility. Partnerships with suppliers and VMS were related to SC agility $(\mathrm{p}<0.05)$. Paths between customer relationships and SC agility, and between partnerships with suppliers and flexibility did not show a significant result ( $p>0.05)$. Regarding the low-customisation sample, results suggest that all three independent variables correlate with SC flexibility and agility, except for the relationship between partnerships with suppliers and SC flexibility $(\mathrm{p}>0.05)$. By comparing the results from high and low customisation, H4a was rejected and $\mathrm{H} 4 \mathrm{~b}$ was supported (i.e., the path between customer relationships and agility), which demonstrates that the relationship between variety management activities and supply chain agility differs across levels of customisation. Achieving SC agility thus requires different approaches for different levels of customisation. The partial least squares (PLS) multi-group analysis (MGA) through the bootstrap method (Henseler et al. 2011) also proves the significant difference in coefficients between customer relationships and SC agility $(\mathrm{p}<0.05)$.

Table 7 Results of Structural Equation Modelling

\section{Discussion}


For VMS, three strategies have been suggested in the operations literature as representative: modularity as a product-based strategy, cellular manufacturing as a process-based strategy and postponement (Scavarda et al. 2010; Jacobs et al. 2011) as a structure-based strategy. However, focusing solely on internal operational factors (i.e., VMS) neglects the importance of external integration factors, which can be more crucial for effective management of product variety in an SC. Extensive SC integration is required to handle increased complexity and uncertainty in making decisions (Fisher, 1997; Mendelson and Pillai, 1999; Heikkilä, 2002). Two practices that accomplish integration across an SC are supplier partnering and building closer customer relationships (Vickery et al., 2003). SC flexibility and agility were considered disparate concepts as an internal capability and external competency, respectively (Swafford et al., 2008; Bernardes and Hanna, 2009). The present study empirically confirms this through EFA.

Due to the importance of alignment between variety-related organisational strategy (e.g., cost leadership and differentiation) and SC strategy (e.g., lean and agile) according to the level of customisation (Agarwal et al., 2006; Stavrulaki and Davis, 2010), the influence of VMS, partnerships with suppliers and customer relationships on SC flexibility and agility should be evaluated separately under varying customisations.

The findings reveal that variety management activities, including both internal VMS and external SC integration, are imperative for SC flexibility and agility when product variety increases and could mitigate the trade-off between product variety and SC performance. Findings concerning $\mathrm{H} 1-\mathrm{H} 3$ also suggest that customer relationships and VMS had a greater influence on SC flexibility than did partnerships with suppliers. In contrast, partnerships with suppliers and variety management strategies had a greater effect on SC agility compared with customer relationships. In particular, to obtain the desired SC flexibility under increasingvariety contexts, monitoring customer-service feedback and responding to customers' evolving needs should be sufficiently encouraged. To attain SC agility under a trend of increasing 
variety, joint problem solving and new-product development with suppliers were more significant than customer relationship. In the service sector, customer relationships can be essential to achieve SC flexibility and agility, whereas in this study of the manufacturing sector, the supplier partnership is shown to be a more essential acquisition for SC agility. Comparing the three hypotheses (i.e., H1-H3) for enhancing SC flexibility and agility shows that, first, internal VMSs were most crucial and effective. Second, the combined data also support the interesting notion that partnership with suppliers is more closely correlated with SC agility, whereas customer relationship is closely correlated with SC flexibility.

Separate analyses of low- and high-customisation samples (i.e., H4) provide critical insights into the importance of variety management under varying customisation profiles within a SC. In a high-customisation context in which the focus is on differentiation and market responsiveness (i.e., SC flexibility and agility are the winning criteria), improvements in customer relationships were particularly vital, influencing SC flexibility significantly in comparison with partnerships with suppliers. The results also reveal that, in a highcustomisation context, customer relationships influenced SC flexibility (i.e., reaction capability) rather than SC agility (i.e., reaction time). Instead, partnerships with suppliers and VMS were crucial to achieving SC agility in high-customisation contexts. Note that partnerships with suppliers influenced SC agility (i.e., reaction time) rather than flexibility (i.e., reaction capability) in a high-customisation context. The advantage of increased supplier involvement (e.g., joint product development and problem solving) was that it increased the positive impact on product innovation (Nieto and Santamaria, 2007) and reduced cost and time to market (Ragatz et al., 1997), which can enhance SC agility. Thus, in a high-customisation context, close customer relationships proved the most effective way to increase SC flexibility whereas partnership with the supplier was the most effective way to increase SC agility. 
Although high customisation presented higher collaborative barriers with the supplier, the supplier partnership was most crucial in improving SC agility (i.e., reaction time).

In low-customisation contexts, internal VMS and customer relationships were required for SC flexibility rather than partnerships with suppliers, whereas all variety management activities, including internal VMS, partnerships with suppliers and customer relationships, influenced SC agility. These findings suggest that, in low-customisation contexts, VMS and customer relations were fundamental factors for both SC flexibility and agility. However, partnerships with suppliers promoted SC agility rather than flexibility, similar to the case for high-customisation contexts. Findings from different levels of customisation suggest appropriate strategic focus for organisations in line with the characteristics summarised by Lampel and Minzbug (1996), Shankar and Tiwari (2006) and Stavrulaki and Davis (2010).

Regarding the theoretical implications, the study first establishes the extensive structure required to mitigate the impact of product variety on the SC, in which internal VMS and external integration are suggested to explore the relationships with SC flexibility and agility performance. Second, both SC flexibility (i.e., reaction capability) and agility (i.e., reaction time) are employed as distinct concepts based on literature reviews (Christopher and Towill, 2001; Agarwal et al., 2006; Swafford et al., 2008; Bernardes and Hanna, 2009) and provide different strategic procedures through which the variety issues can be managed. Third, the literature on independent variables such as product, process and structure-based strategies (i.e., VMS), partnerships with suppliers and customer relationships contributes to the theoretical implication as variety management activities (see Table 1). Finally, the study explains empirically the differential effects that customisation as a moderating factor has on relationships between variety management activities and SC flexibility and agility. The differences in characteristics and strategic focus depending on the level of customisation (see Table 2) support the varied relationships through the results of the research. 
The managerial implications include the adoption of approaches to SC flexibility and agility under different levels of customisation. A distinctive feature of the work is its empiricism. Findings support organisational decision making by providing managers with intuitive guidance on how best to manage product-variety issues in SCs under the different customisation profiles that organisations provide. The study also provides empirical evidence of the importance of holistic strategies at the business level to improve SC flexibility and agility by suggesting two significant approaches: internal VMS and external integration with suppliers and customers. In particular, in a high-customisation context (e.g. innovative products), customer relations were the most important activity to enhance SC flexibility whereas partnerships with suppliers were the most critical activity for SC agility. The findings support the complex policy making for the manufacturer, with supplier and customer relations and the goal of product variety.

\section{Conclusion}

Product-variety ambitions for improved competitiveness should be considered in terms of optimising the trade-off between product variety and SC performance. Thus, this study suggests two distinct concepts as dependent variables: SC flexibility and agility. Internal VMS and external integration as independent variables are proposed to achieve the required SC flexibility and agility. Partnerships with suppliers and customer relationships are employed as an external integration. Although internal VMS, such as modularity, cellular manufacturing and postponement, was effective at managing variety and enhancing SC flexibility and agility, external SC integration proved crucial. The findings support the management of variety-related issues to achieve the desired level of SC flexibility and agility in both low- and highcustomisation contexts. Especially in a high-customisation context involving make-to-order or design-to-order structures, partnerships with suppliers (i.e., external factors) were the most 
effective approaches for superior SC agility, whereas customer relationships (i.e., external factors) were the most effective for SC flexibility. However, both internal factors (i.e., VMS) and external factors (i.e., customer relationships and partnerships with suppliers) should be considered to increase SC agility in a low-customisation context.

The first limitation of this study relates to methodology. Although competitive, environmental and cultural disparities exist between countries and regions (Hughes and Morgan 2008), this study focuses exclusively on the manufacturing industries in two countries (the UK and South Korea). The two countries have similar levels of technology (e.g., Top 10), economic development (e.g., G20) and income distribution (e.g., Gini coefficient). In addition, the measurement invariance test proves that the basic structure of the model is cross-culturally stable. Although several tests (i.e., multi-group CFA estimate, measurement invariance test, separate exploratory factor and random split sample analysis) in this research suggest consistent and stable structure across the groups, a potential gap can always exist. Second, the study examines each manufacturer's principal customisation types to investigate relationships with customisation. It then considers only two levels of customisation, low and high, although combinations such as segmented standardisation and customised standardisation rather than single customisation types might well occur. Case studies (e.g., SC performance disparities in mixed customisation contexts) from several countries should be used to enable in-depth examination and to validate extant results (Voss, Tsikriktsis and Frohlich, 2002). Finally, internal VMS focusing on the modular concept requires a broader exploration to cover other potential strategies that might impact business performance. Another topic to be addressed in future research is the impact of product variety on SC performance, including cost efficiency and customer service (see Beamon, 1999), as a function of level of customisation. The ultimate topic for product-variety issues would be to identify the optimised extent of product variety that a company may implement without increasing the cost burden. 


\section{References}

Abdi, M.R. and Labib, A.W. (2004), "Grouping and selecting products: the design key of Reconfigurable Manufacturing Systems", International Journal of Production Research, Vol. 42 No. 3, pp. 521-546.

Agarwal, A.R.S. and Tiwari, M.K. (2006), "Modeling the metrics of lean, agile and leagile supply chain: An ANP-based approach", European Journal of Operational Research, Vol. 173 No. 1, pp. 211-225.

Agrawal, R.K. and Hurriyet, H. (2004), "The advent of manufacturing technology and its implications for the development of the value chain" International Journal of Physical Distribution \& Logistics Management. Vol. 34 No. 3/4, pp. 319-336.

Aitken, J.M.C. and Towill, D. (2002), "Understanding, Implementing and Exploiting Agility and Leanness", International Journal of Logistics: Research and Applications, Vol. 5 No. 1, pp. 59-74.

Amaro, G.L.H. and Kingsman, B. (1999), "Competitive advantage, customisation and a new taxonomy for non-make-to-stock companies", International Journal of Operations and Production Management, Vol. 19 No. 3/4, pp. 349-371.

Armstrong, J.S. and Overton, T.S. (1977), "Estimating Nonresponse Bias in Mail Surveys", Journal of Marketing Research, Vol. 14 No.3, pp. 396-402.

Beamon, B.M. (1999), "Measuring supply chain performance" International Journal of Operations \& Production Management, Vol. 19 No. 3-4, pp. 275-292.

Bernardes, E.S. and Hanna, M.D. (2009), "A theoretical review of flexibility, agility and responsiveness in the operations management literature toward a conceptual definition of customer responsiveness", International Journal of Operations and Production Management, Vol. 29 No. 2, pp. 30-53.

Blecker, T. and Abdelkafi, N. (2006), "Complexity and variety in mass customisation systems: Analysis and recommendations", Management Decision, Vol. 44 No. 7, pp. 908-929.

Byrne, M. (2001), Structural Equation Modelling with AMOS: Basic Concepts, Applications, and Programming, Lawrence Erlbaum Associates, Mahwah, NJ.

Carr, A.S. and Kaynak, H. (2007), "Communication methods, information sharing, supplier development and performance - An empirical study of their relationships" International Journal of Operations and Production Management, Vol. 27 No. 3, pp. 346-370

Chen, I.J. and Paulraj, A. (2004), "Towards a theory of supply chain management: The constructs and measurements" Journal of Operations Management, Vol. 22 No. 2, pp. 119-150.

Chen, F. F. (2007), "Sensitivity of goodness of fit indexes to lack of measurement invariance" Structural Equation Modeling, Vol. 14 No. 3, pp. 464-504.

Cheung, G. W. and Rensvold, R. B. (2002), "Evaluating goodness-of-fit indexes for testing measurement invariance", Structural Equation Modeling, Vol. 9 No. 2, pp. 233-255.

Child, P., Diederichs, R., Sanders, F.H. and Wisniowski, S. (1991), "SMR Forum: The management of complexity", Sloan Management Review, Vol. 33 No. 1, pp. 73-80.

Christopher, M., Peck, H. and Towill, D. (2006), "A taxonomy for selecting global supply chain strategies", International Journal of Logistics Management, Vol. 17 No. 2, pp. 277-287.

Christopher, M. and Towill, D. (2001), "An integrated model for the design of agile supply chains", International Journal of Physical Distribution \& Logistics Management, Vol. 31 No. 4, pp. 235-246.

Clark, K.B. and Fujimoto, T. (1991), Product Development Performance: Strategy, Organization, and Management in the World Auto Industry, Harvard Business Press, Boston.

Cousins, P.D., Lawson, B., Petersen, K.J. and Handfield, R.B. (2011) "Breakthrough scanning, supplier knowledge exchange, and new product development performance", Journal of Product Innovation Management, Vol. 28 No. 6, pp. 930-942.

Craig, C.S. and Douglas, S.P. (1999), International Marketing Research, Wiley, New York.

Das, A, Narasimhan, R. and Talluri, S. (2006), "Supplier integration: Finding an optimal configuration, Science Direct, Vol. 24 No. 5, pp. 563-582. 
Davila, T. and Wouters, M. (2007), "An empirical test of inventory, service and cost benefits from a postponement strategy" International Journal of Production Research, Vol. 45 No. 10, pp. $2245-2267$.

De Groote, X. (1994), "Flexibility and product variety in lot-sizing models", European Journal of Operational Research, Vol. 75 No. 2, pp. 264-274.

Derocher, R.P. and Kilpatrick, J. (2000), "Six Supply Chain Lessons for the Millennium", Supply Chain Management Review, Vol. 3 No. 4, pp. 34-40.

Doran, D. (2005), "Supplying on a modular basis: an examination of strategic issues", International Journal of Physical Distribution \& Logistics Management, Vol. 35 No. 9, pp. 654-663.

Duclos, L.K., Vokurka, R.J. and Lummus, R.R. (2003), "A conceptual model of supply chain flexibility”, Industrial Management and Data Systems, Vol. 103 No. 5/6, pp. 446-456.

Duray, R., Ward, P.T., Milligan, G.W. and Berry, W.L. (2000), "Approaches to mass customisation: configurations and empirical validation", Journal of Operations Management, Vol. 18 No. 6, pp. 605-625.

Faber, N., de Koster, R.B.M. and van de Velde, S.L. (2002), "Linking warehouse complexity to warehouse planning and control structure", International Journal of Physical Distribution \& Logistics Management, Vol. 32 No. 5, pp. 381-95.

Faems, D., Van Looy, B. and Debackere, K. (2005), "Interorganizational collaboration and innovation: Toward a portfolio approach", Journal of Product Innovation Management, Vol. 22 No. 3, pp. 238-250.

Fisher, M., Ramdas, K. and Ulrich, K. (1999), "Component sharing in the management of product variety: a study of automotive braking systems", Management Science, Vol. 45 No. 3, pp. $297-$ 315.

Fisher, M.L. (1997), "What is the right supply chain for your product?", Harvard Business Review, Vol. 75 No. 2, pp. 105-116.

Fisher, M.L., Jain. A. and MacDuffie, J.P. (1995), "Strategies for product variety: Lessons from the auto industry", in Bowman, E. and Kogut, B. (Ed.), Redesigning the Firm, Oxford University Press, New York, pp. 116-154.

Floyd, F.J. and Widaman, K.F. (1995), "Factor analysis in the development and refinement of clinical assessment instruments" Psychological Assessment, Vol. 7 No. 3, pp. 286-299.

Fornell, C. and Larcker, D.F. (1981), "Evaluating structural equation models with unobservable variables and measurement error" Journal of Marketing Research, Vol. 18 No. 1, pp. 39-50.

Galbreath, J. and Rogers, T. (1999), "Customer relationship leadership: A leadership and motivation model for the twenty-first century business", The TQM Magazine, Vol. 11 No. 3, pp. 161-171.

Gerwin, D. (1987), "An agenda for research on the flexibility of manufacturing processes", International Journal of Operations and Production Management, Vol. 7 No. 1, pp. 38-49.

Gerwin, D. (1993), "Manufacturing flexibility: A strategic perspective", Management Science, Vol. 39 No. 4, pp. 395-410.

Goldman, S.L., Nagel, R.N. and Preiss, K. (1995), Agile Competitors and Virtual Organizations: Strategies for Enriching the Customer, Van Nostrand Reinhold, New York.

Groves, G. and Valsamakis, V. (1998), "Supplier-customer relationships and company performance", International Journal of Logistics Management, Vol. 9 No. 2, pp. 51-64.

Hair, F.J., Black, W.C., Babin, B.J. and Anderson, R.E. (2010), Multivariate data analysis: A global perspective, Pearson Education, New Jersey.

Hallgren, M. and Olhager, J. (2009), "Lean and agile manufacturing: external and internal drivers and performance outcomes", International Journal of Operations and Production Management, Vol. 29 No. 10, pp. 976-999.

Handfield, R and Bechtel, C (2002) "The role of trust and relationship structure in improving supply chain responsiveness", Industrial Marketing Management, Vol. 31 No. 4, pp. 367-382.

Handfield, R and Nichols E. (2002), Supply Chain Redesign, Prentice-Hall, Upper Saddle River, NJ.

Heikkilä, J. (2002), "From supply to demand chain management: efficiency and customer satisfaction", Journal of Operations Management, Vol. 20 No. 6, pp. 747-767.

Hendry, L.C. (2010), "Product customisation: an empirical study of competitive advantage and repeat business", International Journal of Production Research, Vol. 48 No. 13, pp. 3845-3865. 
Henseler, J., Sarstedt, M. and Ringle, C.M. (2011), "Multigroup analysis in partial least squares (PLS) path modelling: Alternative methods and empirical results", International Marketing Advances in International Marketing, Vol. 22, pp. 195-218.

Hiroshi, K. and David, B. (1999), "Agility, adaptability and leanness: A comparison of concepts and a study of practice", International Journal of Production Economics, Vol. 60 No. 3, pp. 43-51.

Hughes, P. and Morgan, R.E. (2008), "Fitting strategic resources with product-market strategy: Performance implications", Journal of Business Research Policy, Vol. 61 No. 4, pp. 323-331.

Jacobs, M., Droge, C., Vickery, S.K. and Calantone, R. (2011), "Product and process modularity's effects on manufacturing agility and firm growth performance", Journal of Product Innovation Management, Vol. 28 No. 1, pp. 123-137.

Jeong, J.S., Hong, P. (2007), "Customer orientation and performance outcomes in supply chain management", Journal of Enterprise Information Management, Vol. 20 No. 5, pp. 578-594.

Kekre, S. and Srinivasan, K. (1990), "Broader product line: A necessity to achieve success?", Management Science, Vol. 36 No. 10, pp. 1216-1231.

Ko, K.C. and Egbelu, P.J. (2003), "Virtual cell formation", International Journal of Production Research, Vol. 41 No. 11, pp. 2365-2389.

Kristensson, P., Matthing, J. and Johansson, N. (2008), "Key strategies for the successful involvement of customers in the co-creation of new technology-based services", International Journal of Service Industry Management, Vol. 19 No. 3, pp. 474-491.

Lampel, J. and Mintzberg, H. (1996), "Customizing customisation", Sloan Management Review, Vol. 38 No. 1, pp. 21-30.

Langlois, R. and Robertson, P. (1992), "Networks and innovation in a modular system: Lessons from the microcomputer and stereo component industries", Research Policy, Vol. 21 No. 4, pp. 297313.

Liao, K., Ma, Z., Lee, J.J. and Ke, K. (2011), "Achieving mass customization through trust-driven information sharing: a supplier's perspective”, Management research review, Vol. 34 No. 5, pp. 541-552.

Lusch, R.F., Vargo, S.L. and O'Brien, M. (2007), "Competing through service: Insights from servicedominant logic", Journal of Retailing, Vol. 83 No. 1, pp. 5-18.

Mackelprang, A.W., Robinson, J.L., Bernardes, E. and Webb, G.S. (2014), "The relationship between strategic supply chain integration and performance: A meta-analytic evaluation and implications for supply chain management research", Journal of Business Logistics, Vol. 35 No. 1, pp. 71-96.

Malham, P.B and Sucier, G. (2014), "Measurement invariance of social axioms in 23 conuntries", Journal of Cross-Cultural Psychology, Vol. 45 No. 7, pp. 1046-1060.

Manuj, I. and Sahin, F. (2009), "A model of supply chain and supply chain decision-making complexity", International Journal of Physical Distribution \& Logistics Management, Vol. 41 No. 5, pp. 511-549.

Mason, J.R. and Towill, D.R. (1999), "Using the information decoupling point to improve supply chain performance", International Journal of Logistics Management, Vol. 10 No. 2, pp. 13-26.

Mendelson, H., Pillai, R.R. (1999), "Industry clock speed: Measurement and operational implications", Manufacturing and Service Operations Management, Vol. 1 No. 1, pp. 1-20.

Michel, S., Brown, S.W. and Gallan, A.S. (2008), "An expanded and strategic view of discontinuous innovations: Deploying a service-dominant logic", Journal of the Academy of Marketing Science, Vol. 36 No. 1, pp. 54-66.

Milfont, T.L. and Fischer, R. (2010), "Testing measurement invariance across groups: Applications in cross-cultural research, International Journal of Psychological Research, Vol. 3 No. 1, pp. 111121.

Mintzberg, H. (1988) "Generic strategies: Toward a comprehensive framework", in Lamb, R. and Shrivastava, P. (Ed.), Advances in strategic management, JAI Press, Greenwich, pp. 1-67.

Montreuil, B., Poulin, M. (2005), "Demand and supply network design scope for personalized manufacturing", Production Planning and Control, Vol. 16 No. 5, pp. 454-469.

Nair, A. (2005), "Linking manufacturing postponement, centralized distribution and value chain flexibility with performance", International Journal of Production Research, Vol. 43 No. 3, pp. 447-463. 
Narasimhan, R. and Das, A. (1999), "An empirical investigation of the contribution of strategic sourcing to manufacturing flexibilities and performance", Decision Sciences, Vol. 30 No. 3, pp. 683718.

Narasimhan, R. and Jayaram, J. (1998), "Causal linkages in supply chain management: An exploratory study of North American manufacturing firms", Decision Sciences, Vol. 29 No. 3, pp. 579-605.

Ngai, E.W.T., Chau, D.C.K. and Chan, T.L.A. (2011), "Information technology, operational, and management competencies for supply chain agility: Findings from case studies", The Journal of Strategic Information Systems, Vol. 20 No. 3, pp. 232-249.

Ngai, E.W.T., Cheng, T.C.E., and Ho, S.S.M. (2004), "Critical success factors of web-based supply chain management systems: An exploratory study", Production Planning and Control, Vol. 15 No. 6, pp. 622-630.

Nieto, M.J. and Santamaria, L. (2007), "The importance of diverse collaborative networks for the novelty of product innovation", Technovation, Vol. 27 No. 6, pp. 367-377.

Olhager, J. (2010), "The role of the customer order decoupling point in production and supply chain management", Computers in Industry, Vol. 61 No. 9, pp. 863-868.

Patel, P.C. and Jayaram, J. (2013), "The antecedents and consequences of product variety in new ventures: An empirical study", Journal of Operations Management, Vol. 32 No. 1-2, pp. 3450.

Podsakoff, P.M., MacKenzie, S.B., Lee, J.Y. and Podsakoff, N.P. (2003), "Common method biases in behavioral research: A critical review of the literature and recommended remedies", Journal of Applied Psychology, Vol. 88 No. 5, pp. 879-903.

Poulin, M., Montreuil, B. and Martel, A. (2006), "Implications of personalization offers on demand and supply network design: A case from the golf club industry", European Journal of Operational Research, Vol. 169 No. 3, pp. 996-1009.

Power, D.J., Sohal, A.S. and Rahman, S.U. (2001), "Critical success factors in agile supply chain management: An empirical study", International Journal of Physical Distribution \& Logistics Management, Vol. 31 No. 4, pp. 247-265.

Qiang, T., Mark, A.V. and Ragu-Nathan, T.S. (2001), "The impact of time-based manufacturing practices on mass customisation and value to customer", Journal of Operations Management, Vol. 19 No. 2, pp. 201-217.

Ragatz, G.L., Handfield, R.B. and Scannell, T.V. (1997), "Success factors for integrating supplier into new product development", Journal of Product Innovation Management, Vol. 14 No. 3, pp. 190-202.

Ramdas, K. and Randall, T. (2008), "Does component sharing help or hurt reliability? An empirical study in the automotive industry", Management Science, Vol. 54 No. 5, pp. 922-938.

Ramdas, K. and Spekman, R. (2000), "Chain or shackles: Understanding what drives supply-chain performance", Interfaces, Vol. 30 No. 4, pp. 3-21.

Randall, T. and Ulrich, K. (2001), "Product variety, supply chain structure, and firm performance: Analysis of the U. S. Bicycle Industry", Management Science, Vol. 47 No. 12, pp. 1588-1604.

Ranganathan, C., Dhaliwal, J.S. and Teo, T.S.H. (2004), "Assimilation and diffusion of web technologies in supply-chain management: An examination of key drivers and performance impacts", International Journal of Electronic Commerce, Vol. 9 No. 1, pp. 127-161.

Rudberg, M. and Wikner, J. (2004), "Mass customisation in terms of the customer order decoupling point", Production Planning and Control, Vol. 15 No. 4, pp. 445-458.

Salvador, F., Forza, C. and Rungtusanatham, M. (2002), "Modularity, product variety, production volume, and component sourcing: Theorizing beyond generic prescriptions", Journal of Operations Management, Vol. 20 No. 5, pp. 549-575.

Salvador, F., Rungtusanatham, M. and Forza, C. (2004), "Supply-chain configurations for mass customisation", Production Planning and Control, Vol. 15 No. 4, pp. 381-397.

Scavarda, L.F., Reichhart, A., Hamacher, S. and Holweg, M. (2010), "Managing product variety in emerging markets", International Journal of Operations and Production Management, Vol. 30 No. 2, pp. 205-224.

Schumacker, R. E., and Lomax, R. G. (2004), A Beginner's Guide to Structural Equation Modelling, Lawrence Erlbaum Associates, Mahwah, NJ. 
Sengupta, K., Heiser, D.R. and Cook, L.S. (2006), "Manufacturing and service supply chain performance: A comparative analysis", Journal of Supply Chain Management, Vol. 42 No. 4, pp. 5-16.

Sethi, A.K. and Sethi, S.P. (1990), "Flexibility in manufacturing: A survey", International Journal of Flexible Manufacturing Systems, Vol. 2 No. 4, pp. 289-328.

Sharifi, H. and Zhang, Z. (1999), "A methodology for achieving agility in manufacturing organisations: An introduction", International Journal of Production Economics, Vol. 62 No. 2, pp. 7-22.

Silveira, G.D. (1998), "A framework for the management of product variety", International Journal of Operations and Production Management, Vol. 18 No. 3, pp. 271-285.

Slack, N. (1983), "Flexibility as a manufacturing objective", International Journal of Operations and Production Management, Vol. 3 No. 3, pp. 4-13.

Slack, N. and Chambers, S. (2007), Operations management, Prentice Hall, Harlow

Skipper, J.B. and Hanna, J.B. (2009), "Minimizing supply chain disruption risk through enhanced flexibility", International Journal of Physical Distribution \& Logistics Management. Vol. 39 No. 5, pp. 404-427

Squire, B., Readman, J., Brown, S. and Bessant, J. (2004), "Mass customisation: The key to customer value?", Production Planning and Control, Vol. 15 No. 4, pp. 459-471.

Stank, T.P., Keller, S.B. and Daugherty, P.J. (2001), "Supply chain collaboration and logistical service performance", Journal of Business Logistics, Vol. 22 No. 1, pp. 29-48.

Stavrulaki, E. and Davis, M. (2010), "Aligning products with supply chain processes and strategy", International Journal of Logistics Management, Vol. 21 No. 1, pp. 127-151.

Suarez, F.F., Cusumano, M.A. and Fine, C.H. (1996), "An empirical study of manufacturing flexibility in printed circuit board assembly", Operations Research, Vol. 44 No. 1, pp. 223-240.

Swafford, P.M., Ghosh, S. and Murthy, N. (2006), "The antecedents of supply chain agility of a firm: Scale development and model testing", Journal of Operations Management, Vol. 24 No. 2, pp. 170-188.

Swafford, P.M., Ghosh, S. and Murthy, N. (2008), "Achieving supply chain agility through IT integration and flexibility", International Journal of Production Economics, Vol. 116 No. 2, pp. 288-297.

Syam, S.S. and Bhatnagar, A. (2015), "A decision support model for determining the level of product variety with marketing and supply chain considerations", Journal of Retailing and Consumer Services, Vol. 25, pp. 12-21.

Tan, K.C. and Kannan, V.R. (1998), "Supply Chain management: Supplier performance and firm performance", International Journal of Purchasing and Materials Management, Vol. 34 No. 3, pp. 2-9.

Tan, K.C., Kannan, V.R., Handfield, R.B. and Ghosh, S. (1999), "Supply chain management: An empirical study of its impact on performance", International Journal of Operations and Production Management, Vol. 19 No. 9/10, pp. 1034-1052.

Thonemann, U.W. and Bradley, J.R. (2002), "The effect of product variety on supply-chain performance", European Journal of Operational Research, Vol. 143 No. 3, pp. 548-569.

Tracey, M. and Tan, C.L. (2001), "Empirical analysis of supplier selection and involvement, customer satisfaction, and firm performance", Supply Chain Management: An International Journal, Vol. 6 No. 4, pp. 174-188.

Treville, S.D., Shapiro, R.D. and Hameri, A.P. (2004), "From supply chain to demand chain: The role of lead time reduction in improving demand chain performance", Journal of Operations Management, Vol. 21 No. 6, pp. 613-627.

Tummala, V.M.R., Phillips, C.L.M. and Johnson, M. (2006), "Assessing supply chain management success factors: A case study”, Supply Chain Management: An International Journal, Vol. 11 No. 2, pp. 179-192.

Turker, D. (2009), "Measuring corporate social responsibility: A scale development study", Journal of Business Ethics, Vol. 82, pp. 411-427.

Ulrich, K. and Tung, K. (1991), "Fundamentals of product modularity" in Sharon, A. (Ed.), Design / manufacturing integration, ASME, New York, pp, 73-79. 
Van Donk, D.P. and van Dam, P. (1996), "Structuring complexity in scheduling: a study in a food processing industry", International Journal of Operations \& Production Management, Vol. 16 No. 5, pp. 54-63.

Van Hoek, R.I. (1999), "Postponement and the reconfiguration challenge for food supply chains", Supply Chain Management: An International Journal, Vol. 4 No. 1, pp. 18-34.

Van Hoek, R.I., Harrison, A. and Christopher, M. (2001), "Measuring agile capabilities in the supply chain", International Journal of Operations and Production Management, Vol. 21 No. 2, pp. 126-147.

Voss, C., Tsikriktsis, N. and Frohlich, M. (2002), "Case research in operations management", International Journal of Operations and Production Management, Vol. 22 No. 2, pp. 195-219.

Vickery, S.K., Jayaram, J., Droge, C. and Calantone, R. (2003), "The effects of an integrative supply chain strategy on customer service and financial performance: An analysis of direct versus indirect relationships", Journal of Operations Management, Vol. 21 No. 5, pp. 523-539.

Wan, X., Evers, P. and Dresner, M. (2012), "Too much of a good thing: The impact of product variety on operations and sales performance", Journal of Operations Management, Vol. 30 No. 4, pp. 316-324.

Whang, S. and Lee, H. (1998), "Value of Postponement" in Ho, T.H. and Tang, C.S. (Ed.), Product variety management: Research advances, Kluwer Academic Publishers, Boston, pp. 65-84.

Wang, Y. and Feng, H. (2012), "Custoemr relationship management capability: Measurement, antecedents and consequences", Management Decision, Vol. 50 No. 1, pp. 115-129.

Whipple, J.M., Wiedmer, R. and Boyer, K.K. (2015), "A dyadic investigation of collaborative competence, social capital, and performance in buyer-supplier relationships", Journal of Supply Chain Management, Vol. 51 No. 2, pp. 3-21.

Yadav, S.R., Mishra, N., Kumar, V. and Tiwari, M.K. (2011), "A framework for designing robust supply chains considering product development issues", International Journal of Production Research, Vol. 49 No. 20, pp. 6065-6088.

Yang, B. and Burns, N. (2003), "Implications of postponement for the supply chain", International Journal of Production Research, Vol. 41 No. 9, pp. 2075-2090.

Yeh, K.H. and Chu, C.H. (1991), "Adaptive strategies for coping with product variety decisions", International Journal of Operations and Production Management, Vol. 11 No. 8, pp. 35-47.

Zokaei, K. and Hines, P. (2007), "Achieving consumer focus in supply chains", International Journal of Physical Distribution \& Logistics Management. Vol. 37 No. 3, pp. 223-247.

Zsidisin, G.A. and Ellram, L.M (2001), "Activities related to purchasing and supply management involvement in supplier alliances", International Journal of Physical Distribution \& Logistics Management, Vol. 31 No. 9, pp. 629-646. 


\section{List of Figure}

Figure 1 Research model

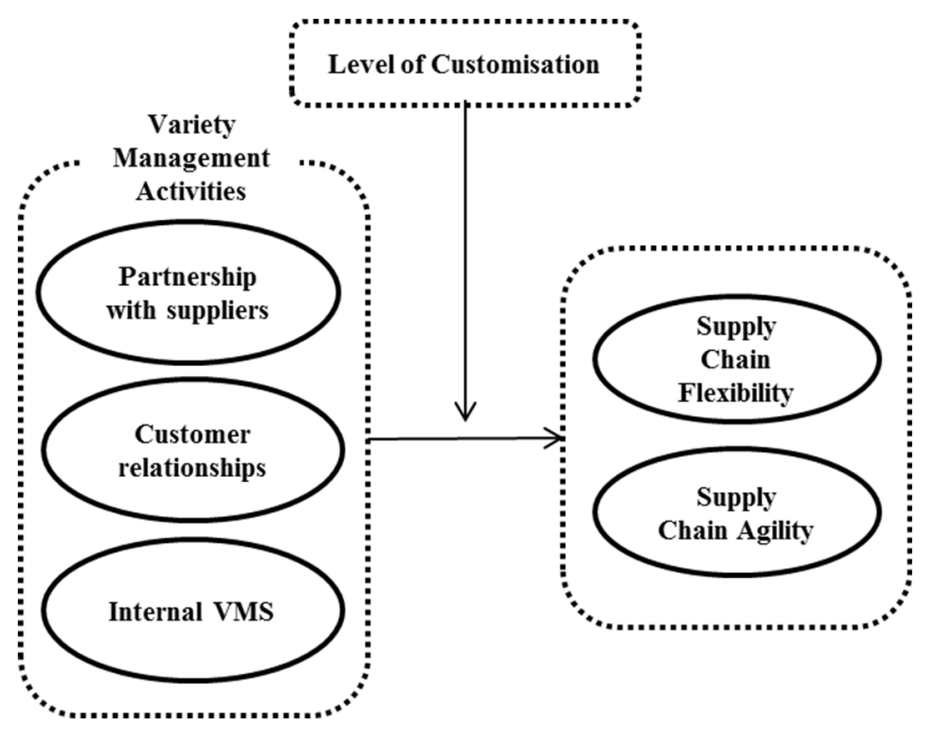


Table 1 Variety Management Activities and Related Literature

\begin{tabular}{|c|c|c|}
\hline Structure & Variable & Related literature \\
\hline \multirow[t]{3}{*}{$\begin{array}{l}\text { Variety } \\
\text { management } \\
\text { strategy } \\
\text { (VMS) }\end{array}$} & VMS1: Modularity & $\begin{array}{l}\text { Ulrich and Tung 1991, Salvador et al. 2002, Doran } \\
\text { 2005, Blecker and Abdelkafi 2006, Scavarda et al. } \\
\text { 2010, Jacobs et al. 2011, Patel and Jayaram 2013, } \\
\text { Syam and Bahatnagar 2015 }\end{array}$ \\
\hline & VMS2: Postponement & $\begin{array}{l}\text { Whang and Lee 1998, Van Hoek, Harrison, and } \\
\text { Christopher 2001, Christopher and Towill, 2001, } \\
\text { Nair 2005, Scavarda et al. 2010, Patel and Jayaram, } \\
2013\end{array}$ \\
\hline & VMS3: Cellular manufacturing & $\begin{array}{l}\text { Yeh and Chu 1991, Ko and Egbelu 2003, Agrawal } \\
\text { and Hurriyet 2004, Abdi and Labib 2004, Blecker } \\
\text { and Abdelkafi 2006, Scavarda et al. } 2010\end{array}$ \\
\hline \multirow[t]{4}{*}{$\begin{array}{l}\text { Partnerships } \\
\text { with suppliers } \\
\text { (PS) }\end{array}$} & $\begin{array}{l}\text { PS1: Trustworthy relationships with } \\
\text { suppliers }\end{array}$ & $\begin{array}{l}\text { Ramdas and Spekman 2000, Handfield and Bechtel } \\
\text { 2002, Ngai, Cheng, and Ho 2004, Tummala, Phillips, } \\
\text { and Johnson 2006, Liao et al. 2011 }\end{array}$ \\
\hline & $\begin{array}{l}\text { PS2: Close relationships during product } \\
\text { development with suppliers }\end{array}$ & $\begin{array}{l}\text { Derocher and Kilpatrick 2000, Power, Sohal, and } \\
\text { Rahman 2001, Ngai, Cheng, and Ho 2004, Cousins et } \\
\text { al. } 2011\end{array}$ \\
\hline & $\begin{array}{l}\text { PS3: Joint problem-solving and } \\
\text { performance evaluation with suppliers }\end{array}$ & $\begin{array}{l}\text { Chen and Paulraj 2004, Tummala, Phillips, and } \\
\text { Johnson } 2006\end{array}$ \\
\hline & $\begin{array}{l}\text { PS4: Sharing sensitive information with } \\
\text { suppliers }\end{array}$ & $\begin{array}{l}\text { Ngai, Cheng and Ho 2004, Liao et al. 2011, Cousins } \\
\text { et al. } 2011\end{array}$ \\
\hline \multirow[t]{4}{*}{$\begin{array}{l}\text { Customer } \\
\text { relationships } \\
(\mathrm{CS})\end{array}$} & $\begin{array}{l}\text { CS1: Anticipate and respond to customers' } \\
\text { evolving needs }\end{array}$ & $\begin{array}{l}\text { Tan and Kannan 1998, Ramdas and Spekman 2000, } \\
\text { Chen and Paulraj 2004, Zokaei and Hines 2007, } \\
\text { Wang and Feng } 2012\end{array}$ \\
\hline & $\begin{array}{l}\text { CS2: Emphasise evaluation of formal and } \\
\text { informal customer complaints }\end{array}$ & $\begin{array}{l}\text { Chen and Paulraj 2004, Ranganathan, Dhaliwal and } \\
\text { Teo 2004, Tummala, Phillips and Johnson } 2006\end{array}$ \\
\hline & $\begin{array}{l}\text { CS3: Monitor and measure customer } \\
\text { service levels }\end{array}$ & $\begin{array}{l}\text { Tan and Kannan 1998, Power, Sohal and Rahman } \\
\text { 2001, Tummala, Phillips and Johnson } 2006\end{array}$ \\
\hline & $\begin{array}{l}\text { CS4: Follow up with customers for } \\
\text { quality/service feedback }\end{array}$ & $\begin{array}{l}\text { Tan and Kannan 1998, Chen and Paulraj 2004, Wang } \\
\text { and Feng } 2012\end{array}$ \\
\hline
\end{tabular}


Table 2 General Characteristics of Customisation Types

\begin{tabular}{|c|c|c|c|c|c|}
\hline \multirow{2}{*}{ Type } & Customization & $\begin{array}{l}\text { Pure/segmented } \\
\text { standardization }\end{array}$ & $\begin{array}{l}\text { Customized } \\
\text { standardization }\end{array}$ & $\begin{array}{l}\text { Tailored } \\
\text { customization }\end{array}$ & Pure customization \\
\hline & Structure & Make to stock & Assembly to order & Make to order & Design to order \\
\hline \multirow{3}{*}{ Product } & $\begin{array}{l}\text { Product variety } \\
\text { Demand uncertainty } \\
\text { Profit margin } \\
\text { Order lead time } \\
\text { Labour skill }\end{array}$ & Low & $\rightarrow$ & & High \\
\hline & $\begin{array}{l}\text { Product life cycle } \\
\text { Forecasting accuracy } \\
\text { Volume }\end{array}$ & High & $\leftarrow$ & & Low \\
\hline & Product type & Functional & $\leftrightarrow$ & & Innovative \\
\hline \multirow{4}{*}{$\begin{array}{l}\text { Manufact } \\
\text { uring }\end{array}$} & Production process & $\begin{array}{l}\text { Continuous, large } \\
\text { assembly/batch }\end{array}$ & $\begin{array}{l}\text { Assembly line } \\
\text { process }\end{array}$ & $\begin{array}{l}\text { Small batch Job } \\
\text { shops }\end{array}$ & Job shops project \\
\hline & Product design & Cost conscious & Modular & & Specialised \\
\hline & Manufacturing focus & Efficiency & Efficiency/flexibili & focus & Flexibility \\
\hline & Production cost & Low & $\rightarrow$ & & High \\
\hline \multirow{5}{*}{ Logistics } & $\begin{array}{l}\text { Number of } \\
\text { intermediaries }\end{array}$ & Large & $\leftarrow$ & & Small \\
\hline & Supplier relationship & \multicolumn{2}{|c|}{$\begin{array}{l}\text { Collaborative } \\
\text { High information sharing } \\
\text { High volume transactions }\end{array}$} & \multicolumn{2}{|c|}{$\begin{array}{l}\text { Opportunistic collaboration } \\
\text { More collaborative barriers } \\
\text { Low volume transactions }\end{array}$} \\
\hline & Customer relationship & \multicolumn{2}{|c|}{ Small number of customer segment } & \multicolumn{2}{|c|}{ Large number of customer segment } \\
\hline & Order fulfilment & Cost driven & $\leftrightarrow$ & & Time driven \\
\hline & Logistics process focus & Efficiency & \multicolumn{2}{|c|}{ Efficiency/flexibility focus } & Flexibility \\
\hline SCM & $\begin{array}{l}\text { Supply chain strategic } \\
\text { capability }\end{array}$ & Lean & \multicolumn{2}{|l|}{ Legality } & Agility \\
\hline Market & $\begin{array}{l}\text { Core competitive focus } \\
\text { (market winner) }\end{array}$ & $\begin{array}{l}\text { Low cost (cost } \\
\text { leadership) }\end{array}$ & \multicolumn{2}{|l|}{$\leftrightarrow$} & $\begin{array}{l}\text { High service } \\
\text { (differentiation) }\end{array}$ \\
\hline
\end{tabular}

Source: Adapted from Lampel and Mintzberg (1996), Agarwal, Shankar, and Tiwari (2006), and Stavrulaki and Davis

(2010) 
Table 3 Main Products by Customisation Level

\begin{tabular}{lcccc}
\hline Manufacturing industry type & $\begin{array}{c}\text { Low customization } \\
\text { (cluster 1) }\end{array}$ & $\begin{array}{c}\text { High customization } \\
\text { (cluster 2) }\end{array}$ & Total & Valid \% \\
\hline Food, beverage, tobacco & 17 & 9 & 26 & 7.2 \\
Wood and furniture & 17 & 15 & 32 & 8.8 \\
Chemical materials and products & 21 & 7 & 28 & 7.7 \\
Non-metal mineral products & 8 & 7 & 15 & 4.1 \\
Fabricated metal products & 14 & 19 & 33 & 9.1 \\
Computer and communication & 16 & 10 & 26 & 7.2 \\
Electronic parts and components & 21 & 20 & 41 & 11.3 \\
Electrical machinery and equipment & 20 & 19 & 39 & 10.7 \\
Transport equipment & 27 & 6 & 8 & 10.5 \\
Textiles and leather & 2 & 2 & 11 & 2.2 \\
Paper products & 9 & 18 & 32 & 3.0 \\
Machinery and equipment & 14 & 3 & 8 & 8.8 \\
Basic metal products & 5 & 5 & 11 & 3.2 \\
Clothing and footwear & 6 & 5 & 15 & 3.0 \\
Other & 10 & 156 & 3.1 \\
Total & 207 & 53 & 100 \\
\hline
\end{tabular}


Table 4 Measurement Invariance Test across the two Countries

\begin{tabular}{lcccccc}
\hline \multicolumn{1}{c}{ Model } & $\chi^{2}$ & $\mathrm{df}$ & $\chi 2 / \mathrm{df}$ & RMSEA & SRMR & CFI \\
\hline $\begin{array}{l}\text { Model 1 } \\
\text { Configural invariance }\end{array}$ & 813.606 & 398 & 2.04 & 0.054 & 0.606 & 0.903 \\
$\begin{array}{l}\text { Model 2 } \\
\begin{array}{l}\text { M1 + Factor loading } \\
\text { invariance }\end{array}\end{array}$ & 832.880 & 415 & 2.01 & 0.053 & 0.609 & 0.903 \\
$\begin{array}{l}\text { Model 3 } \\
\text { M2 + intercept invariance }\end{array}$ & 860.153 & 430 & 2.00 & 0.053 & 0.704 & 0.900 \\
\hline
\end{tabular}


Table 5 Exploratory Factor Analysis

\begin{tabular}{|c|c|c|c|c|c|c|}
\hline & \multicolumn{6}{|c|}{ Factors } \\
\hline & Code & 1 & 2 & 3 & 4 & 5 \\
\hline \multicolumn{7}{|l|}{ 1. Partnerships with supplier (Cronbach's alpha=0.800; CR=0.802) } \\
\hline We develop trustworthy relationships with suppliers & PS1 & $.465^{\mathrm{a}}$ & & & & \\
\hline We have close relationships in product development with suppliers & PS2 & .796 & & & & \\
\hline $\begin{array}{l}\text { We undertake joint problem solving and performance evaluation } \\
\text { with suppliers }\end{array}$ & PS3 & .764 & & & & \\
\hline $\begin{array}{l}\text { We share sensitive information (financial, production, design, } \\
\text { research) with suppliers }\end{array}$ & PS4 & .802 & & & & \\
\hline \multicolumn{7}{|l|}{ 2. Customer relationships (Cronbach's alpha=0.870; CR=0.897) } \\
\hline We anticipate and respond to customers' evolving needs & CR1 & & .730 & & & \\
\hline $\begin{array}{l}\text { We emphasise the evaluation of formal and informal customer } \\
\text { complaints }\end{array}$ & $\mathrm{CR} 2$ & & .774 & & & \\
\hline We monitor and measure customer service levels & CR3 & & .862 & & & \\
\hline We follow up with customers for quality/service feedback & CR4 & & .810 & & & \\
\hline \multicolumn{7}{|l|}{ 3. Variety management strategy (Cronbach's alpha=0.793; CR=0.789) } \\
\hline We use modular production at the assembly stage & $\begin{array}{l}\text { VMS } \\
1\end{array}$ & & & .724 & & \\
\hline $\begin{array}{l}\text { We delay the process that transforms the form or function of } \\
\text { products (Postponement) }\end{array}$ & $\begin{array}{l}\text { VMS } \\
2\end{array}$ & & & .805 & & \\
\hline $\begin{array}{l}\text { We use cellular manufacturing which groups parts with similar } \\
\text { design and processes }\end{array}$ & $\begin{array}{l}\text { VMS } \\
3\end{array}$ & & & .810 & & \\
\hline \multicolumn{7}{|l|}{ 4. Supply chain flexibility (Cronbach's alpha=0.860; CR=0.884) } \\
\hline Ability to change quantity of suppliers orders & FL1 & & & & .752 & \\
\hline Ability to change delivery times of orders placed with suppliers & FL2 & & & & .705 & \\
\hline Ability to change production volume & FL3 & & & & .755 & \\
\hline Ability to change in production mix & FL4 & & & & .737 & \\
\hline Ability to implement engineering change orders in production & FL5 & & & & $.466^{\mathrm{a}}$ & \\
\hline $\begin{array}{l}\text { Ability to alter delivery schedules to meet changing customer } \\
\text { requirements }\end{array}$ & FL6 & & & & .678 & \\
\hline \multicolumn{7}{|l|}{ 5. Supply chain agility (Cronbach's alpha=0.894; CR=0.876) } \\
\hline Ability to rapidly reduce product development cycle time & AG1 & & & & & .747 \\
\hline Ability to rapidly reduce manufacturing lead time & AG2 & & & & & .743 \\
\hline Ability to rapidly increase the level of product customization & AG3 & & & & & .725 \\
\hline Ability to rapidly improve level of customer service & AG4 & & & & & .709 \\
\hline Ability to rapidly improve delivery reliability & AG5 & & & & & .731 \\
\hline $\begin{array}{l}\text { Ability to rapidly improve responsiveness to changing market } \\
\text { needs }\end{array}$ & AG6 & & & & & .710 \\
\hline Ability to rapidly reduce delivery lead time & AG7 & & & & & 683 \\
\hline
\end{tabular}


Table 6 Inter-Construct Correlation Estimates and Related AVEs

\begin{tabular}{l|ccccc}
\multicolumn{1}{c}{} & VMS & PS & CR & FL & \\
\hline VMS & $.555+$ & & & & \\
PS & $.354^{* *}$ & $.576+$ & & & \\
CR & $.333^{* *}$ & $.367^{* *}$ & $.687+$ & $.605+$ & $.540+$ \\
FL & $.409^{* *}$ & $.333^{* *}$ & $.427^{* *}$ & $.615^{* *}$ & 3.23 \\
AG & $.426^{* *}$ & $.384^{* *}$ & $.374^{* *}$ & 3.53 & 0.73 \\
Mean & 3.26 & 3.49 & 4.02 & 0.72 & 0.76 \\
SD & 0.87 & 0.84 & 0.76 & \\
\hline
\end{tabular}

$+=$ Average variance extracted $=\sum$ (standardized loading $\left.)^{2} /\left(\sum \text { (standardized loading }\right)^{2}+\sum \varepsilon_{\mathrm{i}}\right)$

$* *=$ Correlation coefficients significant at $\alpha=0.01$ 
Table 7 Results of Structural Equation Modelling

\begin{tabular}{|c|c|c|c|}
\hline Construct & Path coefficient & t-value & Significance \\
\hline \multicolumn{4}{|l|}{ Combined sample } \\
\hline \multicolumn{4}{|l|}{ 1. Flexibility } \\
\hline Partnerships with suppliers & $+.148^{*}$ & 2.151 & .031 \\
\hline Variety management strategy & $+.320 * * *$ & 4.628 & .000 \\
\hline Customer relationships & $+.269 * * *$ & 4.153 & .000 \\
\hline \multicolumn{4}{|l|}{ 2. Agility } \\
\hline Partnerships with suppliers & $+.251 * * *$ & 3.590 & .000 \\
\hline Variety management strategy & $+.335^{* * *}$ & 4.780 & .000 \\
\hline Customer relationships & $+.148^{*}$ & 2.400 & .016 \\
\hline \multicolumn{4}{|l|}{ High customisation sample } \\
\hline \multicolumn{4}{|l|}{ 1. Flexibility } \\
\hline Partnerships with suppliers & +.132 & 1.204 & .229 \\
\hline Variety management strategy & $+.244 *$ & 2.210 & .027 \\
\hline Customer relationships & $+.351^{* *}$ & 3.046 & .002 \\
\hline \multicolumn{4}{|l|}{ 2. Agility } \\
\hline Partnerships with suppliers & $+.307^{*}$ & 2.549 & .011 \\
\hline Variety management strategy & $+.299 *$ & 2.362 & .018 \\
\hline Customer relationships & +.031 & .281 & .779 \\
\hline \multicolumn{4}{|l|}{ Low customisation sample } \\
\hline \multicolumn{4}{|l|}{ 1. Flexibility } \\
\hline Partnerships with suppliers & +.137 & 1.546 & .122 \\
\hline Variety management strategy & $+.317 * * *$ & 3.426 & .000 \\
\hline Customer relationships & $+.247 * *$ & 3.013 & .003 \\
\hline \multicolumn{4}{|l|}{ 2. Agility } \\
\hline Partnerships with suppliers & $+.215^{*}$ & 2.523 & .012 \\
\hline Variety management strategy & $+.340 * * *$ & 3.805 & .000 \\
\hline Customer relationships & $+.230 * *$ & 2.971 & .003 \\
\hline
\end{tabular}

$\chi^{2}[199]=535.232 ; \mathrm{CFI}=0.919 ; \mathrm{NNFI}=0.906 ; \mathrm{RMSEA}=0.068 ; \mathrm{SRMR}=0.051$

$* \mathrm{p}<0.05 ; * * \mathrm{p}<0.01 ; * * * \mathrm{p}<0.001$ 